\title{
PROFESIONALISME GURU MENIGKATKAN CITRA DUNIA PENDIDIKAN
}

\author{
Syahril Chaniago*
}

\begin{abstract}
The teacher is a person who is authorized and responsible to guide and nurture students, either individually or in groups class and outside of class. Teachers as educators are professionals in charge of planning, implementing the learning process, and assess learning outcomes as well as coaching and training to students.

A fact that must be accepted that the teacher is not akhi-final first-class citizens, but citizens with disabilities. It is well known, the presence of the teacher, not by design but by condition. Teacher is not a pure ideal situation but for various reasons, so it often appears related news is inappropriate teacher behavior. Perhaps this is one reason teachers do not have the character and personality of the teacher should be, certainly more dim the image of the teaching profession.

Self-image as an educator would ease concerns the admissibility of properly by the environment. Personality is a dynamic organization of sitem pshikhofisik determines a unique adjustment to the environment. Personality is an inner state of a person that determines how he looks in adjusting to the environment. There are several factors that determine the development of the personality, which include: actor innate, environmental factors, and the interaction of innate and environmental.

One of the life skills that teachers should have the ability to constantly develop and maintain self-image as an educator. Self-image as an educator would ease concerns the admissibility of teachers with good attendance by the environment. Furthermore, it is very influential to the trust will be given to the task of educating teachers.

As an educator, teacher in daily life are required to always have the selfawareness that mandated profession. The figure of the teacher should be able to personally set an example for students and the environment. Their behavior will always be the public highlights.
\end{abstract}

Keywords: Teacher Character, Personality and Image of the Teaching Profession

\footnotetext{
${ }^{*}$ Dr. Syahril Chaniago, M.Pd. Dosen Universitas Pakuan Bogor
} 


\section{PENDAHULUAN}

Semua orang mengakui, guru memegang kunci utama sukses tidaknya pembelajaran disekolah. Dulu perilaku guru bagaikan mega bintang yang akan menjadi idola siswanya dan masyarakat disekitarnya dalam berbagai hal. Guru bagaikan manusia berjiwa agung. Seperti yang dituliskan oleh Earl v Pullias dan James D Young yang dikutip oleh Widioyastono tentang pandangan masyarakat terhadap guru, yaitu manusia yang serba tahu, serba bisa, dan memiliki wibawa tinggi. Guru dimasa lalu dinilai memiliki kualitas, berkarakter, mempunyai semangat berkorban untuk masyarakat, dan umumnya dikenal mampu membimbing masyarakat

Guru juga merupakan salah satu faktor utama yang berpengaruh terhadap pengembangan sumber daya manusia. Eksistensi guru adalah sebagai orang yang berwenang dan bertanggungjawab untuk membimbing dan membina anak didik, baik secara individu maupun kelompok dikelas maupun diluar kelas (Djamarah, 2004). Guru adalah ujung tombak pendidikan disekolah (Silverius 2003), oleh karena itu guru memegang peran sentral yang teramat utama dalam upaya pengembangan sumber daya manusia. Mantan Presiden Republik Indonesia Abdul Rahman Wahid (Gus Dur) menyatakan bahwa mutu dan inti pendidikan terletak pada guru, oleh sebab itu peran gutu tak dapat diabaikan. Peran guru sangat besar dalam kehidupan seseorang (Republika, Rabu 3 Mei 2000)

.Guru sebagai pendidik merupakan tenaga professional yang bertugas merencanakan, melaksanakan proses pembelajaran, dan menilai hasil pembelajaran serta melakukan pembimbingan dan pelatihan kepada peserta didiknya. Guru sebagai suatu profesi, bukan sekedar pekerjaan biasa, melaikan suatu pekerjaan khusus yang mempunyai ciri - ciri antara lain : keahlian, tanggung jawab, dan rasa kesejawatan (Zahara dan Lisma 1995; Sadirman, 2000). Keahlian yang dimaksudkan adalah menguasai bahan yang dijarkan, memiliki kemampuan untuk mengajarkan bahan ajar tersebut (dapat merencanakan, melaksanakan, dan mengevaluasi kegiatan pembelajaran).

Proses pembelajaran adalah proses membantu siswa belajar, yang ditandai dengan perubahan perilaku baik dari aspek kognitif, afektif, dan psikomotorik.seorang guru hanya dapat dikatakan telah melakukan kegiatan pembelajaran jika ada perubahan perilaku pada diri peserta didik sebagai akibat dari kegiatan tersebut. Ada hubungan fungsional antara perbuatan guru mengajar dengan perubahan perilaku peserta didik. Artinya, proses pembelajaran itu memberikan dampak kepada perkembangan peserta didik.

Bagaimanakah dengan guru saat ini, apakah sesuai dengan 
dilaksanakannya sertifikasi guru terhadap profesinya, akan muncul tokoh pejuang tersebut, seperti yang diharapkan masyarakat?

Ada ungkapan bahwa kehadiran guru yang berkualitas masih sebatas harapan. Pendidikan nasional belum berhasil meningkatkan kecerdasan dan keterampilan anak didik, tetapi juga gagal dalam membentuk karakter dan kepribadian. Sering kali dalam diskusi tentang pendidikan, muncul gugatan dan harapan akan hadirnya guru-guru yang berkualitas dan sosok guru berkualitas baru dibicarakan sebatas wacana. Pendidikan sebagai hak rakyat masik kedodoran termasuk perhatian para guru.

Suatu kenyataan yang harus diterima bahwa yang menjadi guru akhir - akhir ini bukan warga kelas satu, melainkan warha yang memiliki keterbatasan. Sudah umum diketahui, kehadiran guru, bukan by design melainkan by condition. Guru bukan cita-cita murni tetapi karena berbagai alasan keadaan, sehingga sering muncul berita terkait perilaku guru tidak sepantasnya. Mungkin ini salah satu penyebab guru tidak memiliki karakter dan kepribadian guru yang seharusnya, tentu makin meredupkan citra profesi guru.

Apakah kita para calon guru tidak tergugah dan berusaha untuk merubah citra negatif menjadi citra positif terhadap profesi kita. Atau, hanya berlindung dari belas kasihan orang-orang terhadap profesi kita?
Mari kita tinjau kembali keberadaan kita sebagai guru dan citra kepribadiannya.

\section{TINJAUAN PUSTAKA \\ Pengertian Profesi Guru}

Profesi adalah suatu jabatan atau pekerjaan yang menuntut keahlian (expertise) dari para anggotanya. Artinya, tidak dapat dilakukan oleh sembarang orang yang tidak terlatih dan tidak dipersiapkan secara khusus untuk melakukan pekerjaan itu. Misalnya untuk mengoperasi seseorang yeng mempunyai penyakit kanker, dibutuhkan seorang dokter spesialis bedah yang memiliki kemampuan yang diperoleh dari pendidikan khusus untuk itu. Keahlian diperoleh melalui apa yang disebut profesionalisasi, yang dilakukan baik sebelum seseorang menjalani profesi itu (pendidikan/latihan prajabatan) maupun setelah menjalani suatu profesi.

$$
\text { Didi Atmadilaga, secara }
$$

bebas menafsirkan makna "profesi" yang dikemukakan dalam Encyclopedia of Social Science bahwa profesi adalah wewenang praktek suatu kejuruan yang bersifat pelayanan pada kemanusiaan secara intelektual spesifik yang sangat tinggi, yang didukung oleh penguasaan pengetahuan keahlian serta seperangkat sikap dan keterampilan teknik, yang diperoleh melalui pendidikan dan latihan khusus, yang penyelenggaraannya dilimpahkan kepada lembaga pendidikan tinggi 
yang bersama memberikan izin praktek atau penolakan praktek dan kelayakan praktek dilindungi oleh peraturan perundang-undangan yang berlaku, baik diawasi pemerintah maupun asosiasi profesi yang bersangkutan.

Profesi guru adalah suatu jabatan atau pekerjaan sebagai seorang guru yang menampilkan suatu tugas khusus yang mempunyai tingkat kesulitan lebih dari biasa, dan mempersyaratkan waktu persiapan dan pendidikan cukup lama untuk menghasilkan pencapaian kemampuan, keterampilan, dan pengetahuan yang berkadar tinggi.

\section{Citra Diri Positif}

Citra diri sebagai seorang
pendidik akan menyangkut kemudahan diterima atau tidaknya dengan baik oleh lingkungannya. Citra Diri guru berkaitan dengan karakter dan kepribadian guru tersebut.

Apakah kepribadian itu ?

Menurut G.W Allport, pengertian kepribadian adalah suatu organisasi yang dinamis dari sitem pshikhofisik yang menentukan penyesuaian diri yang unik terhadap lingkungannya. Kepribadian adalah merupakan keadaan dalam diri seseorang yang menentukan bagaimana penampilannya dalam menyesuaikan diri dengan lingkungannya.

Menurut Soedarsono, kepribadian adalah totalitas kejiwaan seseorang yang menampilkan sisi yang didapat dari keturunan (orang tua dan leluhur) dan sisi yang didapat dari pendidikan, pengalaman hidup, dan lingkungannya. Berikut dijelaskan bahwa dari keturunan berwujud dalam bakat, kecerdasan dan temptamen. Tempramen ini sangat sukar untuk diubah. Sisi yang didapat dari pendidikan serta dibentuk dan didapat dari pengalaman hidup berwujud pengetahuan, keterampilan dan watak. Watak ini dapat diubah.

Bagaimana Kepribadian itu Berkembang?

$$
\text { Sebagaimana dijelaskan }
$$
diatas, terdapat beberapa faktor yang menentukan dalam perkembangan kepribadian, yaitu meliputi :

a. aktor bawaan

Unsur ini terdiri dari bawaan genetic yang menentukan cirri primer (warna, mata kulit, dan sebagainya) selain itu juga kecenderungan-kecenderungan dasar misalnya kepekaan, penyesuaian diri dan sebagainya.

b. Faktor lingkungan

Faktor lingkungan seperti keluarga, sekolah, atau lingkungan/sosial budaya seperti teman, guru dan sebagainya dapat mempengaruhi terbentuknya kepribadian.

a. Interaksi bawaan serta lingkungan

Interaksi yang terus menerus antara bawaan serta lingkungan menyebabkan timbulnya 
perasaan aku/diriku dalam seseorang.

Pengertian

mengenai

bagaimana pribadi itu terbentuk dan berkembang serta mengenai pribadi diri sendiri merupakan dasar untuk mengetahuiapa yang kita kehendaki dalam kehidupan ini maupun dalam pekerjaan kita dan utnuk mengenal pribadi orang lain.

Sering kali kita ditanya : siapa anda, maka kita cenderung menyebutkan fakta - fakta nyata mengenai diri kita sendiri, misalnya : nama, alamat, pekerjaan dan sebagainya.

Yang sering terlupakan adalah fakta-fakta yang menyangkut siapa saya menurut pikiran saya misalnya :

- Saya ramah

- Saya menarik

- Saya humoris

Mengapa hal tersebut diatas sering terlupakan?

Pada umumnya kita sering tidak memikirkan mengenal keadaan diri kita atau sifat-sifat kita, kalau kita tidak berfikir kesana, karena kita kurang mengenal diri kita sendiri.

Banyak hal yang dapat kita peroleh dari mengenal diri kita sendiri, diantaranya adalah :

- Jika kita sudah mengenal diri kita sendiri akan lebih mudah untuk mengetahui identitas diri

- Untuk mengetahui bagaimana persepsi tentang diri sendiri sehingga tidak dipengaruhi oleh pikiran orang lain mengenai diri kita.
- $\quad$ Mengenal diri kita sendiri untuk mengetahui rencana, kemauan, dan tujuan kita dalam hidup ini. Untuk membangun kepribadian diri, adalah bagaimana kita menurut pikiran kita dapat mempengaruhi :

- Tutur kata

- Tingkah laku

- Cara berpikir

- Cara berpakaian / penampilan

- dan sebagainya

Melalui analisis siapa kita dan siapa kita menurut pikiran kita penting karena :

- melalui analisis ini seseorang dapat mengetahui dan mengenal siapa dirinya sendiri

- melalui analisis ini seseorang dapat mengetahui apa yang dia kehendaki/atau/dilakukan.

- melalui analisis ini seseorang dapat mengetahui kelebihan dan kelemahannya bagaimana mengembangkan aspek-aspek diri itu

- melalui analisis ini seseorang dapat menampilkan gaya hidup yang sesuai dengan konsep dirinya

- melalui analisis ini seseorang dapat menyesuaikan diri dengan lingkunngannya yang berarti penyesuaian diri yang khas.

Tingkah laku sangat menunjukkan apakah kita seseorang yang mempunyai tanggung jawab pribadi yang tinggi atau tidak. Ciri khas seseorang yang mempunyai tanggung jawab pribadi yang tinggi antara lain : 
- Mengerjakan pekerjkaan yang diberikan kepadanya secara tuntas

- Selalu berusaha menghasilkan yang tebaik

- Merasa bertanggung jawab atas semua yang dihasilkan baik yang buruk atau yang jelek.

- Sering menyalahkan diri, jika terdapat hal-hal yang salah.

Berkembangnya rasa tanggung jawab pribadi disebabkan sebagian kecil oleh faktor bawaan dan sebagian dari faktor lingkungan pendidikan dan lingkungan rumah.

Guru adalah profesi yang dikenal sebagai pemberi keterangan, penjelas, pendidik, pembimbing, contoh yang dapat memberi perubahan bagi anak didik ke arah yang dapat lebih baik dari segala dimensi, yang mampu mengembangkan beragam sisi kecerdasan dan akhlaq sebagai pembentuk karakter dan kepribadian anak. Mulyasa (2003) menjelaskan bahwa sikap dan karakteristik guruyang sukses mengajar secara efektif dapat diamati melalui :

- Respek dan pemahaman diri serta control diri yang stabil

- Antusias dan bergairah terhadap bahan, kelasnya, dan seluruh pengajarannya

- Berbicara dengan jelas dan komunikatif

- Memperhatikan individu siswanya

- Memiliki banyak pengetahuan, inisiatif, kreatif dan banyak akal
- Tidak menonjolkan diri

- Menjadi teladan bagi siswanya.

Sedangkan Tilaar mengemukakan bahwa karakteristik profil guru pada abad 21 adalah :

- Memiliki kepribadian matang dan berkembang

- Memiliki penguasaan iptek yang kuat

- Memiliki keterampilan untuk membangkitkan minat peserta didik

- Memiliki pengembangan profesi yang berkesinambungan.

Disini guru yang cerdas memiliki karakter serta kepribadian dengan berbagai kecakapan menjadi tuntutan utama.

Salah satu kecakapan hidup (life skill) yang harus dimiliki guru adalah kemampuan untuk selalu mengembangkan dan merawat citra diri sebagai pendidik. Citra diri sebagai seorang pendidik akan menyangkut kemudahan diterima atau tidaknya kehadiran guru dengan baik oleh lingkungannya. Selanjutnya, sangat berpengaruh kepada kepercayaan yang akan diberikan pada guru untuk tugasnya dalam mendidik.

Sebagai seorang pendidik, dalam kesehariannya guru dituntut untuk selalu memiliki kesadaran diri akan profesi yang diamanahkan. Sosok pribadi guru harus dapat menjadi teladan bagi anak didik dan lingkungan. Perilaku mereka akan selalu menjadi sorotan masyarakat. Sedikit saja cacat dalam berperilaku akan menjadi masalah besar yang 
dapat mencoreng citra kependidikan secara luas. Citra guru berkaitan dengan karakter dan kepribadian guru

Menurut seorang tokoh yaitu G.W Allport, pengertian kepribadian adalah sebagai suatu organisasi yang dinamis dan dari sistim pshikhofisik yang menentukan penyesuaian diri seseorang yang menentukan penyesuaian diri yang unik terhadap lingkungannya.

Menyesuaikan diri dalam arti yang luas, berarti mengubah diri sesuai dengan keadaan linmgkungan secara pasif, dimana kegiatan kita ditentukan oleh lingkungan, atau secara aktif, dimana kita mempengaruhi lingkungan

Dapat dirumuskan bahwa dalam saling hubungan ini, adalah sebagai "interaksi sosial" dimana terjadinya hubungan antara dua atau lebih individu manusia, dimana kelakuan individu yang satu mempengaruhi, mengubahm atau memperbaiki kelakuan individu yang lain, atau sebaliknya.

Ciri Pribadi yang dapat menyesuaikan diri

- Bersikap praktis dan realitis terhadap diri sendiri

- Menyadari keinginan-keinginan, motif-motif dan gaya-gaya hidup pribadi

- Memiliki harga diri

- Merasa nyaman dan aman secara psikologis

- Mampu memberi kasih sayang

- Mampu menerima kasih saying

- Memiliki produktivitas
- Mengetahui tingkatan-tingkatan stres pribadi

- Dapat mendorong pengawasan lingkungan pribadinya daripada dengan pasrah menerima keadaannya.

- Melancarkan suatu perubahan sewaktu seseorang menjadi resah

- Lentur dalam tingkah laku

- Mengetahui saat bilamana merasa cemas atau tidak.

\section{Membangun citra diri positif Mulai dari mencintai diri sendiri}

Mencintai diri sendiri bukan berarti kita menjadi orang yang sombong dan takabur. Mencintai diri sendiri lebih cenderung kepada mensyukuri apa yang allah berikan kepada diri kita. Dalam ilmu psikologi populer, mencintai diri sendiri berarti adalah kita memiliki citra diri yang positif.

Apa pentingnya mencintai diri sendiri ini? Manfaat apa saja yang dapat kita raih dari memiliki citra diri positif?

Pentingnya citra diri yang positif adalah bagaimana yang kita pikirkan tentang diri kita sendiri. "You are what you think". Ini adalah kalimat pepatah luar negeri, maksudnya adalah jika kita memiliki citra diri positif, maka kita akan mengalami berbagai macam hal positif sesuai dengan apa yang kita pikirkan.

Banyak ahli percaya bahwa orang yang memiliki citra positif adalah orang yang beruntung. Citra diri positif membuat mereka 
menikmati banyak hal yamng menguntungkan, antara lain :

1. Membangun percaya diri

Citra diri yang positif secara ilmiah akan membangun rasa percaya diri, yang merupakan salah satu kunci sukses. Orang yang mempunyai citra diri positif tidak akan berlama-lama menangisi nasibnya yang sepertinya terlihat buruk. Citra dirinya yang positif mendorongnya untuk melakukan melakukan sesuatu yang masih dapat ia lakukan. Ia akan fokus pada hal-hal yang masih bisa dilakukan, bukannya pada hal-hal yang sudah tidak dapat ia lakukan lagi. Dari sinilah terdongkrak rasa percaya diri orang tersebut.

2. Meningkatkan daya juang

Dampak langsung dari citra diri positif adalah semangat juang yang tinggi. Orang yang memiliki citra diri yang positif, percaya bahwa dirinya jauh lebih berharga daripada masalah, ataupun penyakit yang sedang dihadapinya. Ia juga bisa melihat bahwa hidupnya jauh lebih indah dari segala krisis dan kegagalan jangka pendek yang harus dilewatinya. Segala upaya yang dijalaninya dengan tekun untuk mengalahkan masalah yang sedang trejadi dan meraih kembali kesuksesan yang sempat. Inilah daya juang yang lebih tinggi yang muncul dari orang dengan citra diri positif.

\section{Manfaat Citra Diri yang positif}

Seseorang yang memiliki citra diri yang positif akan mendapat berbagai mnafaat, baik yang berdampak positif bagi dirinya sendiri maupun untuk orang-orang disekitarnya. Manfaat - manfaat yang terasakan oleh seseorang yang memiliki citra diri positif dan lingkungannnya tersebut adalah:

1. Membawa Perubahan Positif

Orang yang mempunyai citra diri yang positif senantiasa mempunyai inisiatif untuk menggulirkan perubahan positif bagi lingkungan tempat ia berkarya. Meraka tidak akan menunggu agar kehidupan menjadi lebih baik, sebaliknya mereka akan melakukan perubahan untuk membuat kehidupan menjadi lebih baik.

Masalah pengangguran tidak akan membuat orang bercitra diri positif mencak-mencak dan memaki pemerintah. Orang seperti ini akan berusaha mencari dan membuat lapangan pekerjaan bagi diri dan lingkungannya. Hingga ia dapat menyakinkan investor dan memulai usahanya, lapangan pekerjaan pun akan terbuka. Perubahan positif tidak hanya terasakan oleh dirinya, namun juga oleh lingkungannya

2. Mengubah Krisis Menjadi Keberuntungan

Selain membawa perubahan positif, orang yang memiliki citra positif juga mampu mengubah krisis menjadi kesempatan 
untuk meraih keberuntungan. Citra diri yang positif mendorong orang menjadi pemenang dalam segala hal. Menurut orang-orang yang bercitra positif, kekalahan, kegagalan, kesulitan, hambatan sifatnya hanya sementara. Fokus perhatian mereka selalu tertuju kepada kondisi yang tidak menguntungkan tersebut, melainkan fokus mereka diarahkan pada jalan keluar.

Seringkali kita memandang pada pintu yang tertutup terlalu lama, sehingga kita tidak melihat bahwa ada pintu-pintu kesempatan lain yang terbuka untuk kita. Kita sering kali memandang dan menyesali kegagalan, krisis dan masalah yang menimpa terlalu lama sehingga kita kehilangan harapan dan semangat untuk melihat kesempatan lain yang sudah terbuka bagi kita.

John Forbes Nash, pemenang nobel bidang ilmu pengetahuan ekonomi dan matematika, justru merasa tertantang ketika mengalami soal matematika atau permasalahan ekonomi yang sulit. Kesulitan-kesulitan ini menurut Forbes, merupakan kesempatan untuk membuktikan kemampuannya memecahkan masalah tersebut. Kesulitan dan masalah dalam matematika dan ekonomi, mendorongnya untuk mencari cara-cara baru yang lebih efektif dan kreatif sebagai solusi bagi permasalahannya tersebut.

\section{Cara Memiliki Citra Diri Positif}

Setelah kita menyadari betapa pentingnya memiliki citra diri yang positif dan manfaat memiliki citra diri yang positif, tentunya kita junga memiliki keingintahuan bagaimana membangun citra diri yang positif. Berikut hal - hal yang harus dilakukan untuk membentuk citra diri yang positif :

- Persiapan

Salah satu cara membangun citra diri positif adalah melalui persiapan. Dengan persiapan yang cukup, kita menjadi lebih yakin akan kemampuan kita meraih suskses. Keyakinan ini merupakn modal dasar meraih keberuntungan. Dengan melakukan persiapan, kita sudah berhasil memenangkan separuh dari pertarungan. Persiapan menuntun kita untuk mengantisipasi masalah, mencari alternative solusi dan menyusun strategi sukses. Persiapan dapat diwujudkan dengan mencari ilmu pengetahuan yang mendukung kita dalam menyelesaikan suatu masalah. Persiapan juga berarti latihan fisik dan strategi begi atlet-atlet olah raga.

- Berpikir Unggul Untuk membangun citra diri yang positif, kita harus berpikir unggul. Cara berpikir unggul seperti ini akan mendorong kita untuk senantiasa berusaha menghasilkan karya terbaik. 
Mereka tidak akan berhenti sebelumdapat

mempersembahkan sebuah mahakarya. Muhamad Ali petinju asal Amerika Serikat telah menjadi petinju legendaris dengan segudang prestasi yang membanggakan. Semua ini dapat diraih Ali karena selalu berpikir unggul. Setiap kali bertanding, yang dipikirkan oleh Ali adalah kemenangan. Ali tidak pernah berpikir kalah, tetapi selalu berpikir menang. Dengan tujuan kemenangan, Ali dan pelatih serta semua yang mendukungnya berlatih dan menyusun strategi untuk membukukan kemenangan yang sudah dipikirkan sebelumnya.

- Belajar Berkelanjutan

Selain melalui persiapan yang tepat serta berpikir unggul, citra diri positif juga bisa dibangun melalui komitmen pada pembelajaran berkelanjutan. Hasil belajar akan membawa perubahan positif dengan menambah nilai bagi orang yang berhasil mendapatkan pemngetahuan ataupun keterampilan baru, yang bisa dijadikannya modal untuk maju meraih sukses. Tanpa semangat untuk senantiasa mengembangkan diri, orang yang sudah memiliki citra diri positif bisa saja lalu kehilangan citranya tersebut karena tidak dianggap "unggul" lagi atau tidak mampu menambah nilai bagi masyarakat sekitar melalui karya-karya yang dihasilkannya.

Seringkali orang yang sudah berada di tingkat atas merasa tak perlu lagi untuk belajar. Ia memandang remeh untuk belajar lagi. Ia berpikir "toh, aku sudah sukses". Orang seperti ini lebih enggan lagi untuk belajar pada orang yang lebih rendah pada dirinya. Hasilnya, ketika ia dirundung masalah, keberhasilannya pun menurun. Orang yang lebih rendah yang terus belajar akan menggantikannya dan menangani masalah dengan lebih baik.

\section{Interpesonal Skill (Kemampuan Berinteraksi Antar individu)}

Lincahnya kita dalam pergaulan atau baiknya dalam kehidupan pergaulan kita (Social Life) belum berarti kita mempunyai keluwesan dalam bergaul.

Memang biasanya orang yang luwes dalam bergaul lebih mudah lagi meningkatkan kemampuannya untuk berinteraksi dengan individu-individu yang dijumpai baik dalam kehidupan pribadi maupun dengan individu di lingkungan pekerjaan.

Kemampuan untuk berinteraksi dengan orang lain sehingga apa yang terjadi dalam interaksi tersebut dapat diterima dengan baik oleh yang terlibat didalamnya dan apa yang diharapkan dalam interaksi tersebut dapat tercapai tanpa mebuat orang - orang lain yang terlibat merasa 
dimanfaatkan. Kemampuan ini yang akan menunjang suksesnya pergaulan kita dan keberhasilan ini menjadi sangat penting jika pekerjaan kita terlibat dengan banyak orang atau pegawai lainnya misalnya yang bekerja di bagian personalia, humas, pemasaran dan lain sebaginya.

\section{Komunikasi Produktif}

Komunikasi Produktif akan tercapai apabila masing-masing pihak yang terlibat merasa puas dalam arti menerima bentuk reaksi yang sebagaimana diharapkan, sehingga menunjang kelangsungan komunikasi.

Pengembangan diri guru dimulai dari pemahaman mengenain aku/diriku dan melalui analisis diri diketahui siapa yang menurut pikiran saya, setelah itu pengembangan diri memasuki tahap-tahap mengenai pribadi individu-individu lain yang sering kita temui dalam kehidupan seharihari, baik dalam kehidupan pribadi maupun kehidupan profesional kita sebagai seorang guru.

Dengan mengenal pribadipribadi tersebut dan dengan dilengkapi oleh pengetahuan teknikteknik pengembangan diri lainnya seperti : rasa tanggung jawab, cara bergaul yang baik, berinteraksi secara efektif, serta berkomunikasi secara produktif.

Diharapkan dengan pengetahuan - pengetahuan tersebut kita akan lebih profesional dan mapan dalam membina karir sebagai guru. Sehingga "Citra diri guru" akan mewarnai kehidupan guru, kapanpun dan dimanapun orang akan selalu mengenangnya sebagai guru dan pada akhirnya akan menaikkan citra pendidikan Indonesia ke arah yang diharapkan bangsa ini.

Guru sebagai pendidik merupakan tenaga professional yang bertugas merencanakan, melaksanakan proses pembelajaran, dan menilai hasil pembelajaran serta melakukan pembimbingan dan pelatihan kepada peserta didiknya. Proses pembelajaran adalah proses membantu siswa belajar, yang ditandai dengan perubahan perilaku baik dari aspek kognitif, afektif, dan psikomotorik.seorang guru hanya dapat dikatakan telah melakukan kegiatan pembelajaran jika ada perubahan perilaku pada diri peserta didik sebagai akibat dari kegiatan tersebut. Ada hubungan fungsional antara perbuatan guru mengajar dengan perubahan perilaku peserta didik. Artinya, proses pembelajaran itu memberikan dampak kepada perkembangan peserta didik.

Untuk mencapai itu semua, sebagai seorang yeng professional terhadap profesinya, sebagai guru harus mampu memiliki citra diri positif. Hal - hal yang harus dilakukan untuk membentuk citra diri yang positif :

- Persiapan 
Salah satu cara membangun citra diri positif adalah melalui persiapan. Dengan persiapan yang cukup, kita menjadi lebih yakin akan kemampuan kita meraih suskses. Keyakinan ini merupakn modal dasar meraih keberuntungan.

- Berpikir Unggul

Untuk membangun citra diri yang positif, kita harus berpikir unggul. Cara berpikir unggul seperti ini akan mendorong kita untuk senantiasa berusaha menghasilkan karya terbaik.

- Belajar Berkelanjutan

Selain melalui persiapan yang tepat serta berpikir unggul, citra diri positif juga bisa dibangun melalui komitmen pada pembelajaran berkelanjutan. Hasil belajar akan membawa perubahan positif dengan menambah nilai bagi orang yang berhasil mendapatkan pemngetahuan ataupun keterampilan baru, yang bisa dijadikannya modal untuk maju meraih sukses.

\section{DAFTAR PUSTAKA}

Chris Verdiansyah, 2007. Membongkar Budaya. Jakarta: PT Kompas Media Nusantara

Djaman Satori, dkk. 2007. Profesi Keguruan. Jakarta : Universitas Terbuka

M. Toha Anngoro, dkk. 2007. Metode Penelitian. Jakarta : Universitas Terbuka

Somarsono, Soedarsono.2002. Character Building. Jakarta : PT Elex Media Komputindo

Wahyudin,Dinn, dkk. 2006. Pengantar Pendidikan. Jakarta : Universitas Terbuka

www.google.com "Manajemen Diri" by Wirawax

Soedijarto, 2008, Landasan dan arah pendididkan Nasional kita, Jakarta; PT Kompasa Media Nusantara. 